\title{
The State of Research on Inter-Korean Relations Based on KJIR and KJIS Articles
}

\begin{abstract}
Seongji Woo
The purpose of this article is to review articles on inter-Korean relations that have appeared in KJIR (Korean Journal of International Relations) and KJIS (Korean Journal of International Studies) since 2001. KJIR and KJIS contributors for the last sixteen years have been at the forefront of vigorously spreading knowledge on inter-Korean relations. Increasingly, we are witnessing the advance of articles that are empirically sound, methodologically sophisticated, and theoretically profound. Thanks to authors' hard work, we now know more about our subfield than ever before. The authors have covered issues of engagement, conflict behavior and nuclear adventures, stable peace, human rights and humanitarian assistance, and nationalism and unification. I review $K J I R$ and $K J I S$ articles in turn along their themes and conclude by identifying future tasks for Korean Studies scholars. Through developing and trying to solve common puzzles, we may expect to come up with not only continued accumulation of knowledge but also creation of new vocabularies and theories in inter-Korean relations. With the current state of our subfield being what it is, it will not be long before we witness the rise of creative and innovative works solving the great puzzles in our research probes.
\end{abstract}

Key Words: inter-Korean relations, North Korea, South Korea, engagement, human rights

$\mathrm{T}$ he purpose of this article is to review articles on inter-Korean relations that have appeared in KJIR (Korean Journal of International Relations) and KJIS (Korean Journal of International Studies) since 2001. ${ }^{1}$ The purview of this review includes the themes of inter-Korean interactions and exchanges, Seoul's North Korea policy, Pyongyang's South Korea policy, North Korean nuclear issues, security of the Korean Peninsula, and unification matters. Each Korea's

*Seongji Woo (sjwoo@khu.ac.kr) is Professor at the School of International Studies, Kyung Hee University. His research interests are North Korean politics, inter-Korean relations, and East Asian politics. Recently, he has published "Power Transition and Inter-Korean Dialogue in the Early 1970s" (Korea Journal, Summer 2016).

${ }^{1}$ For the earlier reviews on inter-Korean relations covering the latter half of the twentieth century and the early twenty-first century, see Jeong Se-Hyun (1988) and Woo Seongji (2007). In this article, the author has placed the family name first for Korean names.

The Korean J ournal of International Studies Vol.14, No.3 (December 2016), 507-524. http://dx.doi.org/10.14731/kjis.2016.12.14.3.507

(c) 2016 The Korean Association of International Studies 
domestic issues and one Korea's dealings with other surrounding countries or the international community have been excluded from analysis. For instance, articles on North Korean-Chinese relations, U.S.-North Korean relations and the U.S.South Korean alliance are not dealt with here. Neither do we cover South, or North, Korea's development issues nor North, or South, Korea's domestic political programs or cultural identities.

KJIR and KJIS contributors for the last sixteen years or so have been at the forefront of vigorously spreading knowledge on inter-Korean relations. Increasingly, we are witnessing the advance of articles that are empirically sound, methodologically sophisticated, and theoretically profound. Thanks to authors' hard work, we now know more about our subfield than ever before. The authors have covered issues of engagement, conflict behavior and nuclear adventures, stable peace, human rights and humanitarian assistance, and nationalism and unification. I review KJIR and KJIS articles in turn along their themes and conclude by identifying future tasks for Korean scholars.

\section{ENGAGING NORTH KOREA: PROS AND CONS}

Given the time context of this article, it is not surprising to find that many KJIR and KJIS authors have ventured to discuss the nature of South Korea's engagement policy toward North Korea. Since Kim Dae-jung's presidency, South Korea has been passionately debating which policy is suitable for encouraging liberalization of the North Korean regime, reducing tensions on the Korean Peninsula, and expediting reunification of the two Koreas. Chun Chaesung's (2003)article makes an effort to differentiate engagement from containment, appeasement, or isolation conceptually. Engagement is seen as a type of foreign policy to persuade a revisionist state to accept the status quo through continuous contacts and exchanges. According to the author, the Sunshine Policy is devoid of concrete theoretical or ideological foundations.

Lee Jeong-jin (2003) studies South Korea's North Korea policy under Presidents Chun Doo-hwan, Roh Tae-woo, Kim Young-sam and Kim Dae-jung and finds that presidential influence on decision making was not affected by democratization and popular support helped presidents to continue their course. Differing from the common perception that President Kim Young-sam's influence on foreign policy was quite limited, Park Yong-Soo (2015) argues that Kim firmly held the initiative by secretively and skillfully delegating his authority to a certain agent and switching his agents at the right moment.

Shin Jin (2003) and Lee Byounghee (2003) are critical of the Sunshine Policy 
in that it did not produce genuine cooperation between the two Koreas and failed to make South Korea more secure against North Korea's nuclear and missile threats. Lee Kyeongho (2007) is worried that the Sunshine Policy is wreaking havoc in U.S.-ROK relations. For him, it is important to solidify WashingtonSeoul ties first and, then, proceed to enhance U.S.-North Korea relations and South-North relations in tandem. While critics are worried about Seoul's unilateral and excessive concessions to Pyongyang, Park Jae-Min (2003) argues that a limited level of reciprocity existed between the two Koreas between 1998 and 2002 contrary to popular perceptions.

Bae Seong In's advice (2001) for deepening inter-Korean cooperation is to specialize in and accelerate issue-specific cooperation in IT industry that is less susceptible to political intervention. Lee Chung-Hee (2002) studies various social organizations' perceptions and attitudes toward South Korea's unification policy and urges consensus building among different organizations with various ideological orientations for successful implementation of inter-Korean cooperation and reconciliation.

Yang Gil-Hyun (2012) condemns President Lee Myung-bak's North Korea policy as inflexible and unilateral, giving no chance to political negotiations. While examining Roh Moo-hyun administration's and Lee Myung-bak administration' s North Korea policy, Heo Inhye discovers serious policy discontinuities and seeks remedies in democratic governance based on people's participation and the rule of law. Dean J. Ouellette (2013) suggests that South Korean government's support for NGO engagement with a focus on renewable energy assistance may be helpful in advancing President Park Geun-hye's "trust politics" toward North Korea.

In a democratic society such as ours, it might be natural to have a variety of opinions on unification policy. Scholars will continue to debate the merits and demerits of embracing and punishing the North Korean regime for some time to come. As liberal and conservative coalitions take turns in assuming power and put into practice their assumptions and preferences, we have gathered a hoard of information on what works and what does not and, if it works, under what conditions. Instead of sticking to old ideology and programs, we need to be open to learn from the past experiences. Both liberal and conservative ideas and programs have strong points and weak ones.

There is a plenty of room for the possibility of mutual learning and cross-cooperation between liberal and conservative coalitions. Korean scholars should stand at the forefront in producing solutions to our liberal-conservative divide, instead of stoking tensions and conflict between them. Our scholarly medicine for the ills of our social discourses and schisms may include the following: how do we eval- 
uate the nature of the North Korean regime; what kind of engagement works best facing Pyongyang; what issues need to prioritized; what lessons need to be learned from each other's programs; and how do we weave together engagement programs and denuclearization efforts.

\section{NORTH KOREA'S CONFLICT BEHAVIOR, NUCLEAR AMBITIONS AND OUR RESPONSES}

We, South Koreans, spend a great deal of time trying to understand North Korea' s attitudes and behavior and decipher the motives and desires behind its actions. Knowing why Pyongyang does what it does is an important part of our enquiry of discovering patterns and waves in inter-Korean relations as well as of finding clues for building a more pacific and prosperous Korean Peninsula.

Through a close reading of Rodong Sinmun, Jeon Mi Young (2004) ventures to analyze the evolution in North Korea's perception of South Korea and its unification policy in the 1960s. She takes note of the rise of the theory of South Korean revolution that heavily relies on South Korean people's resistance and revolutionary strengths to realize reunification of Korea. Oh Il-Whan (2003) traces Pyongyang's tactics toward Seoul since the 2000 inter-Korean summit. He cautions that the North had been stoking inner-tensions among South Koreans and using the South's benevolence to gain access to the latter' s capital and technology.

Using logistic models, Kim Hong-Cheol (2012) finds that North Korea turns provocative when it is undergoing leadership transitions. He also finds that North Korea's economic downturn, its leadership change, and U.S. involvement in war jointly affect its external conflict behavior. Ko Dae-Won (2001) is curious whether North Korea's sense of relative deprivation correlates with its military conflict behavior toward South Korea. Jo Dong-Joon (2004) points to the irony that each Korea's pursuit of self-reliant defense backfired and caused a spiral of the security dilemma resulting in security aggravation and increased dependence on its allies by forcing the other Korea to accelerate its pace of militarization. Woo Seongji (2013) maintains that North Korea constituted a revisionist power under Kim Jong-il for it proactively attempted to upend the prevailing balance of power between the two Koreas as manifested by its persistent pursuit of nuclear and missile programs.

Hwang Jihwan (2006) analyses the first and second North Korean nuclear crises utilizing the prospect theory. He asserts that Pyongyang becomes risk- 
acceptant in order to avoid potential losses but turns risk-averse and conciliatory when faced with prospects of catastrophic losses. Hwang Jihwan (2009) argues that Pyongyang's reference points function as a reliable indicator of its external and internal perceptions and behavior. Cha Jae Hoon's article (2011) reviews major research issues and problems on North Korean nuclear negotiations. He suggests that we should pay more attention to changes in North Korea' $s$ positions and strategic and tactical maneuvers. According to Sohn Yong-Woo (2012), North Korea's nuclear adventure is driven by its desire for security maximization from the neorealist perspective. Kwon Hyorim and Kim Yongho (2014) trace the origins of North Korea's first nuclear test in 2006 to threat perception changes in relative power and shared identity.

Facing the ever-mounting nuclear and missile threats from its northern counterpart, it has become imperative for South Korea to find solutions for curbing Pyongyang's resoluteness in Weapons of Mass Destruction (WMD) programs as well as means to safeguard our lives and properties. Curiously, Park Yong-Soo (2007) is of the opinion that Northeast Asian countries' soft balancing against the United States and South Korea's moderation efforts had a calming effect on North Korea's nuclear crises in the early 1990s and the early 2000s. Lee Inbae (2003) calls for a multilateral cooperative security mechanism including the notion of comprehensive security as a means to solve the North Korean nuclear problems.

After surveying several cases of and options for denuclearization, Cho SoonGoo (2005) goes on to argue that building trust among the concerned parties is most important and Chae Kyu-Chul (2004) proposes a Ukrainian model of solutions to end Pyongyang's nuclear programs. Jang Eun Seok (2010) considers political implications for inter-Korean relations of entering Proliferation Security Initiative (PSI) while Park Tong Hyong (2010) mulls over how to better handle the verification issues regarding North Korea's nuclear programs.

Kim Taehyun (2012) argues that the success of coercive diplomacy hinges on a favorable balance of military capabilities, political will to withstand political pressure, and shrewd diplomatic skills of allowing the opponent to have the last clear chance to avoid the catastrophe. Jung Jaewook (2012) advises that South Korea's proactive deterrence should combine military punishment and denial of North Korea's political objectives and our coercive efforts need to be complemented by some positive offers. He also calls for active cooperation with neighboring countries to avoid unnecessary escalation.

Chung Haang Sok (2001) argues that the U.S.' Missile Defense (MD) reflects its desire for absolute hegemony based on power preponderance over other nations. He sees that George W. Bush's MD is aggravating inter-Korean relations and 
advises South Korea to stay away from it. Roh Byung-Ryul (2002) is also critical of Bush's MD policy and asks South Korea not to become entangled with it. According to him, MD deployment would force South Korea to be overly dependent on the U.S. and cause heightened tensions on the Korean Peninsula due to opposition from China and North Korea. He is also pessimistic about MD's military effectiveness.

According to Park Hwee Rhak (2013), South Korea's capabilities of and readiness for deterrence by punishment and deterrence by denial are both unsatisfactory. He calls for "precision deterrence strategy" incorporating surgical and preemptive strikes against critical and significant targets. Park Hwee Rhak (2015) discusses South Korea's capabilities for deterrence by denial against North Korea's nuclear weapons. According to him, deterrence by punishment based on the U.S. promise of extended deterrence is not sufficient to ensure South Korea' s safety against North Korea's nuclear and missile threats. He makes a cogent plea for beefing up our preparatory measures for deterrence by denial, preemptive strike, and civil defense.

The Park Geun-hye government's decision to deploy THAAD (Terminal High Altitude Area Defense) is causing stirs in our community. Time has passed since the first North Korean nuclear crisis and only part of the early assumptions and discussions on the North Korean nuclear issues remains relevant today. North Korea's strategic imperatives have become clearer and its nuclear and missile capabilities more formidable; yet, we are at a loss in finding an exit strategy to this paramount problem. It is urgent to think about measures necessary to make South Korea safe from North Korea's nuclear and missile threats. Our efforts for heightened security need not stop at deterring North Korean threats and defending our turf. Some of us hope for a more improved security system that is at once robust and durable. In the next section, we turn to the issues related to building a peace system on the Korean Peninsula.

\section{MAKING PEACE ON THE KOREAN PENINSULA}

Koreans have long dreamed of establishing a lasting and stable peace on the Korean Peninsula. And we have made multiple endeavors to realize such dreams. At this point, we cannot say that we have achieved a lot so far. In some sense, it might even be said that we are backpedaling in this regard both peninsula-wide and regionally.

In the past, South Korea took a gradual approach in which it focused on mak- 
ing progress in economic, social, and cultural fronts first and then tackling political and military issues. North Korea leaned toward a more direct approach by emphasizing political and military talks first. Given that North Korea is aggressively building its nuclear and missile programs, Kim Young Jae (2003) counsels that we should remain cautious and patient. He believes that our priority needs to be focused on building a foundation favorable for building a peace system.

According to Jang Young-Kwon (2012), the future of the Korean Peninsula will rely on whether we will be able to establish sustainable peace here. The so-called peace complexes theory guides us to erect economic peace, cultural peace, and political-military peace. Ahn Mun Suk (2012) wants to apply the concept of international society from the English School to better understand and improve inter-Korean relations and focuses on mutual recognition, shared identity, institution-building, and cooperation. Hwang Jin-Hwoan (2001) probes military confidence-building measures and arms control between South and North Korea. Han Yong-Sup (2009) also traces the shortcomings of the past arms control efforts on the Korean Peninsula and calls for resumption of security dialogue with attention to confidence building and verification measures.

Park Jeong Jin (2013) compares the 1972 Basic Treaty of East and West Germany and 1992 Basic Agreement of North and South Korea and notes that the success of West Germany hinged on its focus on processes of building peace with East Germany as well as with other neighboring countries instead of clinching the final outcome of unification in haste. His research directs us to seek peace first and unification later. In line with this gradual approach, many authors are calling for the establishment of a peace regime in the Korean Peninsula. For such a regime to take effect, it seems that we need to conclude a peace treaty between the two Koreas and institutionalize multilateral cooperation among the neighboring countries (Kim Kyung Ho 2002 and 2003; Kim Sung-Joo 2002).

We generally seem to concur that we need to build a peace regime here. But what factors are needed and what factors are preventing it? Woo Seongji (2008) seeks to explain the dynamics of inter-Korean reconciliation in the early 1970s. He argues that some external political shocks were essential in bringing about inter-Korean dialogue but they somehow fell short of causing expectancy revisions in South and North Korean decision makers. Hong Yong-Pyo (2008) investigates the armistice agreement in 1953, the July 4th Joint Communique in 1972, the Basic Agreement in 1992, and the June 15th Joint Declaration in 2000 in order to discover why we have so far failed to settle inter-Korean confrontation. For him, finding ways to lessen the incompatibility of ideological identity and core (security) interests is integral in building a peace system. As both sides have increasingly become more tolerant of each other's political identities, the author 
holds that it is urgent for both the U.S. and South Korea to guarantee some kind of security assurances toward North Korea.

Kim Taehwan (2002) is curious why we cannot establish sustainable peace on the Korean Peninsula despite South Korea's ongoing efforts of engagement policy since 2000. He concludes that sustainability ultimately depends on North Korea's internal changes. North Korea' s transformation is hampered by, firstly, domestic resistance deeply rooted in its system and, then, the new regional order of Northeast Asia emerging in the aftermath of the collapse of the Cold War. He mentions neoliberal globalization and post-socialist transformation are two critical components of the new international order.

Why is our dream of stable peace drifting away? Some authors find fault in the systemic characteristics while, still, others point the finger at the usual suspect, that is, North Korea. Agent-specific treatment as well as systemic solutions seems insufficient and one-sided as the Korean Peninsula's problems have been created as a joint production of both unit and systemic level forces. Probably, solutions will be discovered as we treat the symptoms at two levels, agent and structure simultaneously. Additionally, we cannot boast that we know a lot about what conditions or variables are conducive to the rise of dialogue and de-escalation between the two Koreas. As such, we need to put more energy into understanding the right mixture of ingredients under which the two Koreas turn more conciliatory and compromising.

\section{HUMAN RIGHTS AND HUMANITARICAN ASSISTANCE}

South Korean society is deeply divided in how to approach North Koreas' human rights problems. Thanks to North Korean defectors' repeated testimonies, now we tend to agree that wide-spread and even systematic human rights violations exist in North Korea. But we still cannot agree on who or what is responsible, which dimensions of broadly-defined human rights deserve priority, and how we can best deal with it (Woo Seongji 2006).

Kang Dong Wan (2008) finds that, in terms of governance structure of policy networks involved in supporting North Korea, the Roh Moo-Hyun administration showed open and horizontal features whereas the Kim Dae-Jung administration closed and vertical. Lee Sookja (2009) is critical about South Korean governments' attitudes toward North Korean defectors in China under Presidents Kim Dae-Jung and Roh Moo-Hyun. She notes that South Korea had been overly passive about enforced repatriation of defectors by the Chinese government and 
calls for a revamp of so-called "quiet diplomacy."

Choi Dae Seok's work (2004) seeks to evaluate the Roh Moo-Hyun administration' s humanitarian policy toward North Korea. He notes that its policies on separated families, humanitarian aids, and North Korean refugees have become increasingly pragmatic and precautious. His concern is this cautious approach may result in the loss of driving forces for vigorously carrying out humanitarian and reconciliation causes. Shin Yul (2001) defines the separated family issue as part of family rights and uses survey techniques to seek room for improvement in Seoul's policy to facilitate reunions across North and South Korea. Rhee Yoojin (2011) and Park Tong Hyong (2012) explore the ways to apply the "responsibility to protect (R2P)" to the North Korean case.

Lee Won-Woong's work (2007) is an effort to observe how North Korea itself perceives human rights issues. Pyongyang has its own standards stressing state independence and national prerogatives over individual liberal rights, much like in other issue areas. North Korea has been responding to external criticisms with flat-out rejection, backlash, and highly selective accommodation. For him, North Korea's ruling elites' perception change is critical in making progress on the human rights front.

Suh Bo-hyuk (2016) argues that we should pay more attention to human security and the right to peace to overcome militarism and politicization of the human rights issues on the Korean Peninsula. Choi Dae Seok and Park Young Ja (2011) lament that our research on North Korean defectors has failed to produce highquality works despite growth in volumes. According to them, the research has often been repetitive and hollow in terms of prescriptive suggestions.

So far, KJIR and KJIS authors have attempted to evaluate South Korean governments' human rights and humanitarian policies, understand how North Korea responds to foreign pressure, and offer critical reviews on the state of our research on the theme. All of these themes will for sure continue to be the main staple of Korean researchers. Above all, however, what we need is the right strategy for making Pyongyang respectful of the globally recognized norms. That would surely entail foreign pressure of some kinds and certain international actors. However, such pushes from external forces would be incomplete without the accompanying pull of domestic actors and institutions. Then, our next scholarly endeavor should be aimed at facilitating perception and attitude changes among the elites and masses of North Korea.

Secondly, scholars need to think about how we will weave human rights into the overall North Korea and unification policy. What should be prioritized? How does a focus on human rights affect the overall status of improving inter-Korean relations? Does normative orientation help or hinder making progress toward North 
Korean denuclearization? Are they all connected or separated issues? Thirdly, we need a better policy for taking care of new settlers from the North. Integration after unification is an integral part of reuniting members of the divided nation for a long period of time. The efforts for national integration may start from designing policies that are aimed at securing psychological and material support for the new settlers in the South.

\section{NATIONAL DIVISION AND REUNIFICATION}

The remaining titles, not incorporated under the previous sections, are all included in this last section, which shall cover national division, the Korean War, nationalism and unification matters. We start with Yoo Nayoung's piece (2015), which adopts Waltz's three images to account for the national division following liberation from Japanese colonial rule. She is pushing for a proposition saying that American and Soviet leaders' perceptions, domestic politics of South and North Korea as well as the Cold War global and regional confrontational structure between the two superpowers jointly generated the birth of two Koreas on the peninsula. Comparing the two Koreas' constitutions, Park Myung-Lim (2009) underscores that both strived to be recognized as the sole legitimate entity while disavowing the existence of the other.

The Korean War consolidated the Cold War. It was essential in sealing and shaping the structure of East-West confrontation for decades to come in its early stage. It also contributed to the rise of a Cold Peace, i.e., it prevented confrontation to flare up into a hot war. Through the Korean War, major powers learned how to control regional conflict and how to avoid direct military confrontation between themselves (Kim Myongsob 2003). Kim Hak-joon's review article on the origins of the Korean War (2002) sees Stalin as its chief architect. He concludes that new documents from the Soviet archives weakens revisionist and neo-revisionist arguments and supports traditional ones.

Heo Man-ho (2013) traces and analyzes the processes of the armistice talks that aimed to end the bloody Korean War based on negotiation theory and diplomatic documents. He laments that South Korea was poorly represented at the occasion partially because President Rhee Syng-man insisted on continuing the warfare. He faults the United States in that it failed to draw the military demarcation line (MDL) favorably despite its edges on air and naval military competitiveness.

As a divided nation, the ideology of nationalism looms large over our political discourse. The modern form of Korean nationalism stems from the struggle for 
independence over Japanese colonialism in the first half of the twentieth century. The two Koreas' political leaders have persistently used nationalist ideology to solidify their power bases and to further their political gains. Recently, South Korean nationalism has assumed more open, democratic, and globalized features whereas the North Korean version has a strong tilt toward more closed, exclusive, and anti-imperialist ones (Jeon Mi Yeong 2003).

Some authors ventured to propose unification schemes of various sorts. Kang Jong Il (2001) and Eom Sang-Yoon (2003) call for unification via permanent neutralization. Noh Tae-Goo (2009) calls for the dialectical logic of the humancentered philosophy in order to bring about peaceful reunification of the two Koreas. Based on the lessons drawn from German unification in 1990 via the union of currency, economy, and society, Han Jong-Soo (2002) argues that confederation is more suitable for Korean unification than federal or unitary state.

As we expect to see more documents from Russian, Chinese, and American archives, there remains a plenty of room for reinterpreting the origins and processes of the Korean War. One thing that will remain unchanged is that the 1950 war was the beginning of the fierce rivalry that has defined the lives of the Korean people for a long time. Even in the age of globalization, nationalism has survived and gives meanings to peoples around the world as a definitive ideology. As a divided nation, Koreans will continue to seek a guide from some form of nationalism: It is about time that Korean scholars sophisticate our discourses on nationalism and unification formulas as fit for the challenges of the new century.

\section{FUTURE TASKS}

Korean scholars are now conducting research with diverse techniques spanning traditional case studies and large- $\mathrm{N}$ statistical analyses. A variety of research methods are used to investigate sundry topics related to inter-Korean studies. Compared to the old studies of the Cold War decades, current studies are more theoretically informed and methodologically sophisticated while covering more diverse topics. Scholars are experimenting with multiple techniques to unlock the mysteries of dynamism in North-South interactions.

While celebrating recent academic achievements, it might be worthwhile to identity a few areas that we need to pay more attention to. First, there seems to be a robust and, rather, persistent intellectual wall between what might be called traditionalists and theoreticians. By traditionalism, I refer to the works that pursue an in-depth and ideographic knowledge based on a single case study. The 
other is interested in generating a hypothesis or a theory that is applicable beyond the Korean case.

The former cherishes texts whereas the latter values contexts. The former reads North (South) Korean publications sometimes meticulously and tries to understand how North (South) Koreans sees issues themselves. The latter often skips the original texts to rely on secondary materials. The former accuses the latter as ignorant of North (South) Korean realities. The latter criticizes the former for failing to distinguish between ideographic facts and repetitive patterns. It seems that both text and context matter. A constant dialogue and mutual learning between the two would do a great service in improving the standards of our scholarship.

Our subfield is, to a non-negligible degree, swayed by government policies. Certain topics and issues receive more limelight under conservative coalitions whereas others attract more attention under liberal coalitions. Given the nature of our subject, perhaps, this is unavoidable. The policy orientation of our work is not necessarily something that is good or bad by itself. But, at least, we need some sense of diversification of labor between policy research and academic research. It is unavoidable that sometimes government or reality drives the course and content of our research. But still some others should remain focused on puzzles and conduct theory-oriented research.

In many ways, our scholarship reflects the social divide along the ideological line. Many of our works are driven by ideology, and not by theory. Ideologicallycharged researches tend to refuel and deepen the social divide instead of curing the social ills or providing solutions. Our task needs to be reducing, and not maximizing, social polarization by accurate diagnosis and adequate treatment. Scholars should strive to provide solutions for serious national problems.

Our research is suffering from lack of creation of innovative concepts and theories. We see many articles applying established concepts and theories to Korean cases. How much conceptual clarification or theoretical fine-tuning is gained in the process remains unclear. We import and consume theories lavishly but export too little. This persistent deficit in knowledge trading is discomforting. We are looking into Korean cases with either borrowed lenses or lenses lacking in precision. Where do we start to overcome such epistemic deficits? We need enhanced communication among Korean scholars. Oftentimes, many of our works are not related to one another's. Scholars are busy digging their own trenches without thoughtful consideration of what others are doing and why they are doing what they are doing.

The whole picture of the academic community looks separate and detached as we talk and think past each other, and not toward each other. We need more research that builds on other fellows' scholarly works in the hope of adding a 
brick to an unfinished structure instead of trying to build separate buildings all the time. Developing common puzzles that we can share may be a place to start. We can concur on a set of puzzles and scholars may jump in to provide answers with whatever concepts, hypotheses, theories, methods, skills, or paradigms that they feel comfortable with. Through those processes, we may expect to come up with not only accumulation of knowledge but also creation of new vocabularies and theories in the subfield of inter-Korean relations. With the current state of our subfield being what it is, it will not be long before we witness the rise of creative and innovative works solving the great puzzles of inter-Korean relations.

\section{REFERENCES}

Ahn, Mun Suk. 2012. "The History of North-South Korean Relations and Prospect of Its Future from the Perspective of Theory of International Society." Korean Journal of International Relations [In Korean] 52(3), 7-31. Bae, Seong In. 2001. " North Korea's IT Industry and Inter-Korean Cooperation." Korean Journal of International Relations [In Korean] 41(4), 149-169.

Cha, Jae Hoon. 2011. "20 Years North Korean Nuclear Negotiation: Major

Research Issue \& Problem." Korean Journal of International Relations [In Korean]51(3), 135-151.

Chae, Kyu-Chul. 2004. "A Study of Scenarios of and Solutions to North Korean

Nuclear Issues." Korean Journal of International Relations [In Korean] 44(4), 143-147.

Cho, Soon-Goo. 2005. "Empirical Nuclear Weapon Dismantles and Searching for Managing Fissile Materials of North Korea Peacefully." Korean Journal of International Relations [In Korean] 45(3), 195-217.

Choi, Dae Seok. 2004. "Issues and Prospects of Humanitarian Policies of the Rho Administration Toward North Korea." Korean Journal of International Relations [In Korean] 44(1), 235-254.

Choi, Dae Seok and Park Young Ja. 2011. "Research Trend and Priority Subject of Policy Research on North Korean Defector: Soul-searching and Communication beyond Quantitative Growth." Korean Journal of International Relations [In Korean] 51(1), 187-215.

Chun, Chaesung. 2003. "Theoretical Basis of 'Engagement Policy' and South

Korea's Reconciliation and Cooperation Policy toward the North."

Korean Journal of International Relations [In Korean] 43(1), 231-251.

Chung, Haang Sok. 2001. “The American Missile Defense and its Influence over 
Korean Peninsular." Korean Journal of International Relations [In Korean] 41(3), 117-140.

Eom, Sang-Yoon. 2003. "Analysis on the Suggestion of One Korea via Permanent

Neutralization by Mike Mansfield, Kim Sam-Kyu, and Kim Yong-Jeung under the 2nd Republic of Kore." Korean Journal of International Relations [In Korean] 43(2), 97-121.

Han, Jong-Soo. 2002. "The German Experience in the Stage of the Confederation and the Unification Program for the Korean Peninsula." Korean Journal of International Relations [In Korean] 42(2), 175-194.

Han, Yong-Sup. 2009. "Arms Control Approach to Security Issues on the Korean Peninsula: Theory, Evaluation, and Prospects." Korean Journal of International Relations [In Korean] 49(5), 101-128.

Heo, Inhye. 2012. "A Search for a Democratic Governance in South Korea's North Korea Policy." Korean Journal of International Relations [In Korean] 52(2), 169-196.

Heo, Man-ho. 2013. "Analysis of Korean War Armistice Talks: Establishment of Military Demarcation Line between Strident Antagonists." Korean Journal of International Relations [In Korean] 53(4), 113-163.

Hong, Yong-Pyo. 2008. "Why Have Attempts to Settle Inter-Korean Conflict Failed?: Lessons for Peace Building in the Korean Peninsula." Korean Journal of International Relations 48(5), 133-152.

Hwang, Jihwan. 2006. "Prospect Theory and North Korea's Nuclear Policy: The First and Second North Korean Nuclear Crisis." Korean Journal of International Relations [In Korean] 46(1), 79-101.

. 2009. 'Face-Saving, Reference Point, and North Korea' s Strategic

Assessments." Korean Journal of International Relations 49(6), 55-75.

Hwang, Jin-Hwoan. 2001. "Military CBMs and Arms Control between South and

North Korea: Issues and Trends." Korean Journal of International Relations [In Korean] 41(3), 193-211.

Jang, Eun Seok. 2010. "Meaning of South Korean Participating in Proliferation Security Initiative (PSI) and Guidelines for Future PSI Cooperation."

Korean Journal of International Relations [In Korean] 50(1), 191-215.

Jang, Young-Kwon. 2011. "A New Invention and Expansion of Peace: Focused on Peace Zone between South Korea and North Korea." Korean Journal of International Relations [In Korean] 51(3), 105-134.

Jeon, Mi Yeong. 2003. "A Comparison between Nationalism of South and North Korea: An Idea of Unification." Korean Journal of International Relations [In Korean] 43(1), 185-207. . 2004. 'North Korea's South Korea Policy in the 1960s: Analysis of 
'Rodong Sinmum.' " Korean Journal of International Relations [In Korean] 44(3), 265-287.

Jeong, Se-Hyun. 1988. "South-North Korean Relations and Unification Problem." Korean Journal of International Relations [In Korean] 28(1), 107-119.

Jo, Dong-Joon. 2004. " The Oxymoron of Defense Self-Reliance in the InterKorean Relationship." Korean Journal of International Relations [In Korean] 44(3), 25-49.

Jung, Jaewook. 2012. "North Korea' s Military Provocation and Embodiment of Proactive Deterrence." Korean Journal of International Relations [In Korean] 52(1), 137-159.

Kang, Dong Wan. 2008. "A Study on Governance of North Korea Support Policy through Policy-Network Analysis: Focusing on Policy Decision Making Process." Korean Journal of International Relations [In Korean] 48(1), 293-323.

Kang, Jong Il. 2001. "A Study of Korean Peninsula Reunification via Permanent

Neutrality." Korean Journal of International Relations [In Korean] 41(1), 93-116.

Kim, Hak-joon. 2002. "Stalin Initiated the Korean War." Korean Journal of International Relations [In Korean] 42(1), 297-307.

Kim, Hong-Cheol. 2012. "How to Deter North Korea' s Military Provocations."

Korean Journal of International Studies 10(1), 63-93.

Kim, Kyung Ho. 2002. "An Alternative Plan for the Korean Peninsula Peace: By the Focus of Multilateral Security and Cooperation System." Korean Journal of International Relations [In Korean] 42(2), 195-215. . 2003. "A Suggestion for Peaceful Settlement of Tension on the Korean Peninsula." Korean Journal of International Relations [In Korean] 43(3), 211-234.

Kim, Myongsob. 2003. "The Impact of the Korean War on the Construction of the Cold War System." Korean Journal of International Relations [In Korean] 43(1), 115-133.

Kim, Sung-Joo. 2002. "Relations of Two Koreas and Some Suggestions for PeaceRegime Formation in the Korean Peninsula after the 6.15 Summit Meeting." Korean Journal of International Relations [In Korean] 42(3), 205-223.

Kim, Taehwan. 2002. "North-South Korean Reconciliation under a New International Order: A Post-Cold War Analytical Framework." Korean Journal of International Relations [In Korean] 42(3), 179-203.

Kim, Taehyun. 2012. "Deterrence Failures and Coercive Diplomacy: The Cuban 
Missile Crisis and the North Korean Nuclear Crisis." Korean Journal of International Relations [In Korean] 52(1), 57-83.

Kim, Young Jae. 2003. "The Division of the Korean Peninsula and A New Peace

Regime." Korean Journal of International Relations [In Korean] 43(4), 145-170.

Ko, Dae-Won. 2001. "North Korea's Military Conflictual Behavior Towards South Korea: A Psychological Model." Korean Journal of International Relations [In Korean] 41(4), 127-147.

Kwon, Hyorim and Kim Yongho. 2014. "A Cognitive Analysis on the first North Korean Nuclear Quagmire: Looking for Kim Jong-Il's Perceptional Variants." Korean Journal of International Relations [In Korean] 54(1), 99-132.

Lee, Byounghee. 2003. "The Policy Toward North Korea between South Korea and US: Its Prospect." Korean Journal of International Relations [In Korean] 43(4), 121-144.

Lee, Chung-Hee. 2002. 'Citizen Groups' Perceptions and Ideological Orientations on South-North Korean Relations." Korean Journal of International Relations [In Korean] 42(4), 117-149.

Lee, Inbae. 2003. "A Study on Multilateral Approaches to Resolve the North Korean Nuclear Maze." Korean Journal of International Relations 43(5), 49-71.

Lee, Jeong-jin. 2003. "The Influence of the President and Public Opinion on the Decision-making Process of Northern Policy." Korean Journal of International Relations [In Korean] 43(1), 253-273.

Lee, Kyeongho. 2007. "A Critical Study of Policy toward North Korea and State Autonomy during the Kim Dae-Joong Government Period." Korean Journal of International Relations [In Korean] 47(1), 191-213.

Lee, Sookja. 2009. "Korean Government' s Policy on North Korean Defectors in China: With the Emphasis on the Administration of Kim Dae-Jung and Roh Moo-Hyun." Korean Journal of International Relations [In Korean] 49(5), 251-271.

Lee, Won-Woong. 2007. "International Human Rights Pressure and North

Korea: A Critical Analysis on its Perception and Reactions." Korean Journal of International Relations [In Korean] 47(1), 215-233.

Noh, Tae-Goo. 2009. "Political Practice for Peaceful Reunification: Dialectical Strategy \& Tactics." Korean Journal of International Relations 49(6), 77-98.

Oh, Il-Whan. 2003. "Characteristics of North Korea's Tactics toward South Korea since the South-North Summit Talk and Its Countermeasures." 
Korean Journal of International Relations [In Korean] 43(3), 255-273. Ouellette, Dean J. 2013. "Building Trust in Inter-Korean Relations: A Role for Renewable Energy?" Korean Journal of International Studies 11(2), 327-353. Park, Hwee Rhak. 2013. "Evaluating the Nuclear Deterrence Readiness of South Korea and Searching for a Nuclear Deterrence Strategy against North Korea Based on Nuclear Deterrence Theories." Korean Journal of International Relations [In Korean] 53(3), 147-180.

. 2015. "An Analysis on South Korean Nuclear Deterrence Strategy against North Korean Nuclear Weapons: Re-look at Defense Measures through a Deterrence by Denial." Korean Journal of International Relations [In Korean] 55(2), 293-319.

Park, Jae-Min. 2003. "Reciprocity between North and South Korea, 1998-2002." Korean Journal of International Relations [In Korean] 43(1), 317-338.

Park, Jeong Jin. 2013. "A Comparative Study of the German 1972 Basic Treaty and Korean 1992 Basic Agreement: A Conflict Management System Approach using a 'Divided Nation Conflict Management Model.' " Korean Journal of International Relations [In Korean] 53(2), 99-138.

Park, Myung-Lim. 2009. "Constitutional Making and the State Identity of the Two Koreas: A Comparative and Relational Approach." Korean Journal of International Relations [In Korean] 49(4) 235-263.

Park, Tong Hyong. 2010. "A Study on Verification for North Korea Nuclear Negotiation." Korean Journal of International Relations [In Korean] 5O(1), 120-142.

. 2012. "A Case Study on the Application of 'RtoP' to Libya: Its Implications and Lessons for North Korea." Korean Journal of International Relations [In Korean] 52(3), 287-312.

Park Yong-Soo. 2007. "The Characteristics of the Changed Environment of Korea After 1990s: Focusing on the Cases of 'Pueblo Incident' and 'North Korea's Nuclear Crisis.' " Korean Journal of International Relations [In Korean] 47(2), 51-73.

. 2015. "The Competitive Foreign Policy Management Style of the President Kim Yong-Sam in the Process of First North Korean Nuclear Crisis." Korean Journal of International Relations [In Korean] 55(4), 139-168.

Rhee, Yoojin. 2011. "North Korea and Crimes against Humanity: A 'Responsibility to Protect' Perspective." Korean Journal of International Studies 9(1), 97-118. Roh, Byung-Ryul. 2002. "MD as a New Pattern of Nuclear Policy and Its Impact on the Korean Peninsula." Korean Journal of International Relations [In Korean] 42(1), 73-99.

Shin, Jin. 2003. "Korea's Sunshine Policy and Its Structural Limits." Korean 
Journal of International Relations [In Korean] 43(1), 296-316.

Shin, Yul. 2001. "An Interim Evaluation on the Policy of the Separated Families after the Korean Summit and the Positive Study on an Improvement Plan in Preparation for Its Regularity." Korean Journal of International Relations [In Korean] 41(2), 45-71.

Sohn, Yong-Woo. 2012. "A Study on North Korea's Nuclear Policy from a Neorealist Perspective (1945-2009)." Korean Journal of International Relations [In Korean] 52(3), 257-286.

Suh, Bo-hyuk. 2016. "Resolving the Korean Conflict through a Combination of Human Rights and Human Security." Korean Journal of International Studies 14(1), 53-75.

Woo, Seongii. 2006. "On the Study of North Korea's Human Rights Issues: Controversies and Tasks." Korean Journal of International Relations [In Korean] 46(3), 189-212. . 2007. "Review of Inter-Korean Relations Research." Korean Journal of International Relations [In Korean] 46(Special Edition), 159-182. . 2008. "Evolutionary Expectancy Theory and Inter-Korean Reconciliation in the Détente Period." Korean Journal of International Relations [In Korean] 48(2), 107-126. . 2013. 'Is North Korea a Status Quo Power?: North Korea' s State Orientation under Kim Jong-Il." Korean Journal of International Relations [In Korean] 53(4), 165-190.

Yang, Gil-Hyun. 2012. "A Critical Assessment on the Obama and Myungbak Lee Administration' s Policies toward the North Korean Nuclear Issues from the Semi-Periphery Perspective." Korean Journal of International Relations [In Korean] 52(2), 143-167.

Yoo, Nayoung. 2015. "A Study on Waltz's Three Images and the Origins of the Division of the Korean Peninsula: Based on the Declassified Documents in the Post-Cold War Period." Korean Journal of International Relations [In Korean] 55(2), 7-43. 